Article

\title{
The Artist as Soldier: Howard Cook's Self-Portrait in a Foxhole
}

\section{Sara Woodbury}

American Studies Program, College of William \& Mary, Williamsburg, VA 23187-8795, USA; scwoodbury@email.wm.edu

Received: 7 December 2019; Accepted: 28 February 2020; Published: 10 March 2020

check for updates

\begin{abstract}
In the summer of 1943, Taos artist Howard Cook (1901-1980) traveled to the South Pacific to serve as a correspondent in the U.S. Army's short-lived War Art Unit. During his assignment, Cook produced hundreds of sketches documenting the daily lives of Allied soldiers working there; yet, one group stands out for its subject matter: the artist himself. Collectively titled Self-Portrait in a Foxhole, these works depict Cook taking shelter during an air raid and, together with his writings, offer an invaluable perspective into his interpretation of war through art. This essay explores Cook's wartime oeuvre by examining the Self-Portrait group's depiction of vulnerability. Through an expressionistic use of ink and paint and a compositional emphasis on his passivity, Cook offers a personalized interpretation of combat conditions that underscores his sense of exposure. Although his self-representation initially appears distinct from the more assertive soldiers in his other sketches, when viewed together, they collectively demonstrate Cook's efforts to record a nuanced impression of the war, reflecting a broader tradition of exploring war's deleterious effects on soldiers. More broadly, Cook's oeuvre highlights the significance of the War Art Unit and the potential for more scholarship on this initiative.
\end{abstract}

Keywords: War Art Unit; Howard Cook; World War II; Pacific Theater; South Pacific; war art; self-portrait; twentieth-century art; American art

\section{Introduction}

The jungle itself ... is not a romantic affair the way these sweet advertisements come out in Life with pretty bands of light striking on gorgeous flowers and orchids. (Cook 4 July 1943) ${ }^{1}$

So concluded artist Howard Cook (1901-1980) when describing the South Pacific island of Rendova in a 1943 letter to his wife, fellow artist Barbara Latham (1896-1989). ${ }^{2}$ A two-time Guggenheim fellowship recipient who had received critical acclaim as a printmaker and muralist, Cook had worked primarily in New York and New Mexico before the war, between sleek urban skyscrapers and weathered adobe exteriors. During the summer of 1943, however, he temporarily exchanged both his Manhattan cityscapes and the high desert for the South Pacific, where he served as a correspondent in the U.S. Army's short-lived War Art Unit. Throughout his assignment, Cook produced hundreds of sketches

1 Howard Cook to Barbara Latham, 4 July 1943, shelf 9, box 12, folder 6, Howard Cook Papers, Roswell Museum and Art Center Library and Archives, Roswell, NM.

2 This article developed from a conference paper entitled "'A Solid Green Mess': Howard Cook's World War II Drawings," which I presented at the annual Southwest Art History Conference in Taos, New Mexico on 15 October 2015. I would like to thanks Betsy Fahlman, Teresa Ebie, and the other conference organizers and attendees for their feedback and recommendations. I would also like to thank Marc Simpson for reading an early version of this article and recommending that I focus on Self-Portrait in a Foxhole. I would also like to thank Amberly Meli at the Roswell Museum and Art Center, and June Frosch at the New Mexico Military Institute, for their ongoing assistance in obtaining images. Finally, I would like to express my appreciation and gratitude to the two anonymous reviewers for their suggestions. Any errors, factual or otherwise, are my own. 
documenting Allied activity as studies for future paintings and prints. While many of the finished paintings are housed at the U.S. Army Art Collection, Cook donated his preparatory sketches to the Roswell Museum and Art Center in New Mexico, along with letters he wrote to Latham during his experience. ${ }^{3}$ Together, Cook's art and writing offer substantial insight into the daily lives of American soldiers as they adapted to life in the Pacific Theater.

Yet, within this larger corpus, one group stands out for its subject matter: the artist himself. Consisting of a mixed media drawing, an intaglio print, and an oil painting, the three works collectively titled Self-Portrait in a Foxhole depict the artist taking shelter during an air raid (Figure 1). As examples of an artist explicitly rendering his participation in military action, these works raise several questions concerning their performative roles as war art, both for Cook and for potential viewers. Specifically, Cook's decision to highlight his concealment from potential enemy fire, as opposed to showing himself in a more active role, such as digging the trench, merits closer consideration, both within the context of his wartime oeuvre and the broader corpus of twentieth-century war art.

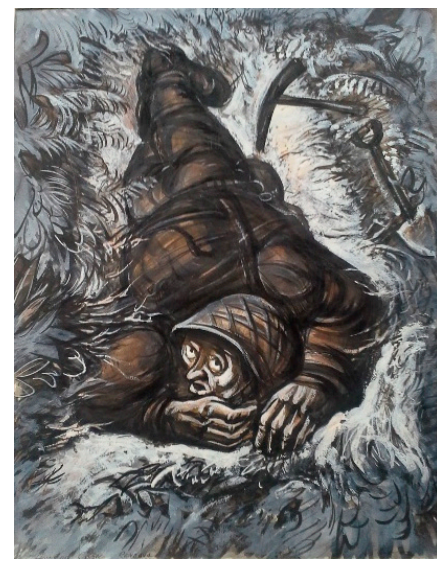

(a)

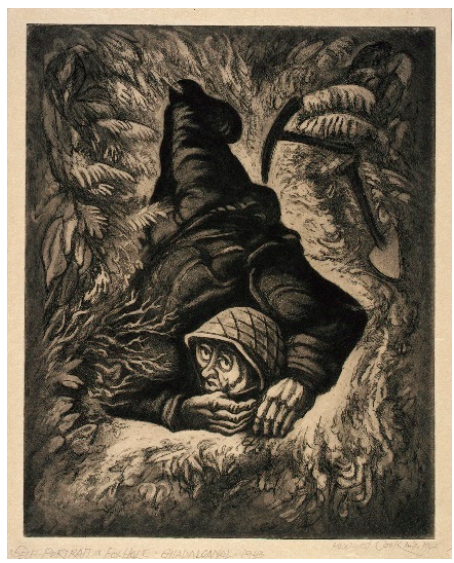

(b)

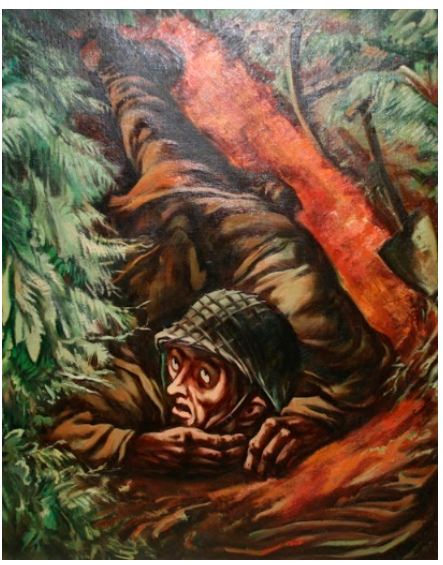

(c)

Figure 1. The three renditions of Self-Portrait in a Foxhole: (a) Howard Cook, Self-Portrait in a Foxhole, Rendova Island, 1943, mixed media on paper. Permanent Collection of the Roswell Museum and Art Center, Gift of the Artist, 1973.031.0227. Used with permission. (b) Howard Cook, Self-Portrait in a Foxhole, 1945, etching and aquatint on paper. Smithsonian American Art Museum 1980.122.95. Used with permission. (c) Howard Cook, Self-Portrait in Foxhole, ca. 1943, oil on canvas. New Mexico Military Institute, Roswell, NM. Used with permission.

This essay explores the Self-Portrait group by examining its depiction of vulnerability. Following a brief overview of Cook's career up to the War Art Unit, I will analyze the three versions of Self-Portrait in a Foxhole and their varying use of media. I will then contextualize the group within Cook's larger wartime oeuvre. Although the Self-Portrait group stands out for its focus on the artist's personal experience, I posit that it highlights themes of vulnerability and exposure that recur throughout his war drawings. Through a gestural use of ink and paint, Cook's self-portraits depart from the clean, rectilinear style that distinguished his earlier work to suggest the dense vegetation of his jungle environs and the absence of a clear battlefront. Simultaneously exposed and concealed, his self-portraits evoke the discomfiting strangeness of the jungle, underscoring the Solomon Islands' role as both protector of and aggressor to the troops stationed there. By showing himself, moreover, a middle-aged, civilian artist taking shelter in a coffin-like foxhole, Cook's self-portraits offer a personalized experience of combat while highlighting passivity as an important part of the war experience. Although his

3 Cook developed a working relationship with the museum and its curatorial staff during the 1960s while participating in what would eventually become the Roswell Artist-in-Residence Program. Cook, and later his estate, donated hundreds of works to the museum, spanning his career from the 1920s into the 1970s. 
self-representation initially appears distinct from the more assertive soldiers in his other sketches, when viewed together, they demonstrate Cook's desire to record a nuanced impression of the war's effects on soldiers as articulated in his writings. Cook's focus on vulnerability situates his work within a broader creative tradition addressing the traumatic effects of warfare as observed by the soldiers who experienced it. More broadly, his art highlights the significance of the War Art Unit as a federal endeavor and the potential for more scholarship on this initiative. ${ }^{4}$

Before describing Cook's career and the Self-Portrait group further, some clarification is necessary regarding his wartime oeuvre. When discussing Cook's war art, this essay will focus primarily on the Roswell Museum and Art Center collection. While some of these works include finished paintings intended for exhibition or publication in magazines, the majority of the collection consists of sketches and preparatory drawings. As such, they were created for the artist's personal use, but with the intention of producing more public work.

\section{Results}

\subsection{Cook and the War Art Unit}

Originally from Massachusetts, Cook attended the Art Students League in New York, where he studied printmaking with Joseph Pennell. An inveterate traveler, Cook visited New Mexico for the first time in 1926 as part of an illustration assignment for Forum magazine. During that initial trip, he met and later married fellow artist Barbara Latham, and the pair divided its time between New Mexico and New York when not traveling on assignment. Cook initially achieved critical acclaim as a Precisionist printmaker and illustrator during the late 1920s, exhibiting his works at such venues as the Weyhe Gallery in New York (Figure 2). Skilled in a variety of printmaking techniques, Cook pulled his own intaglio and relief impressions, while George C. Miller acted as his primary lithographer (Adams 1983, p. 20; Duffy and Duffy 1999, p. 19). Cook's prints from the 1920s and early 1930s often highlight the regional architecture of the places he visited. Whereas his New York impressions feature skyscrapers, bridges, and other modernist structures, for instance, his southwestern prints highlight weathered adobe architecture. For all of these early works, Cook employed a detailed, meticulous style with strong contrasts between light and shadow to emphasize the geometric forms defining his subject matter.

Cook's career continued to thrive during the 1930s. In 1932 and 1934, he received two consecutive Guggenheim fellowships, with the first one taking him to Taxco, Mexico, to study fresco painting, and the second to the rural American South. While he continued to make works highlighting architecture, he also began exploring the human figure more seriously. Through the Treasury Department (Figure 3), he completed frescoes for such buildings as the U.S. Courthouse and Post Office in Pittsburgh, Pennsylvania, and the Hipolito F. Garcia Federal Building in San Antonio, Texas (Duffy and Duffy 1999, p. 22). ${ }^{5}$ As with his earlier prints, Cook continued working in a representational style that emphasized geometric forms, with ample reflected light giving his fresco painting an especially luminous character. As the demand for large-scale frescoes decreased during the early 1940s, Cook began teaching, but he became frustrated with the limited time he could dedicate to his own work (Ebie 2015). With the United States' entry into World War II, however, Cook discovered new opportunities to concentrate on his art without the constraints of a teaching schedule. In 1942, Olin Dows from the Office of War Information commissioned him to illustrate military preparations in Norfolk, Virginia. Cook also published Sammi's Army, a children's book about a young Latinx boy and a retinue of farm animals rescuing their village from invading soldiers (Cook 1943).

4 The most extensive work on Howard Cook that I know of is an unpublished manuscript by Teresa Ebie, former Registrar and Curator of Paintings at the Roswell Museum and Art Center. I am indebted to the insights she shared with me regarding Cook and his career.

5 At the time of its completion in 1939, the 16-panel fresco in San Antonio was the largest post office mural-related project executed by a single artist. 


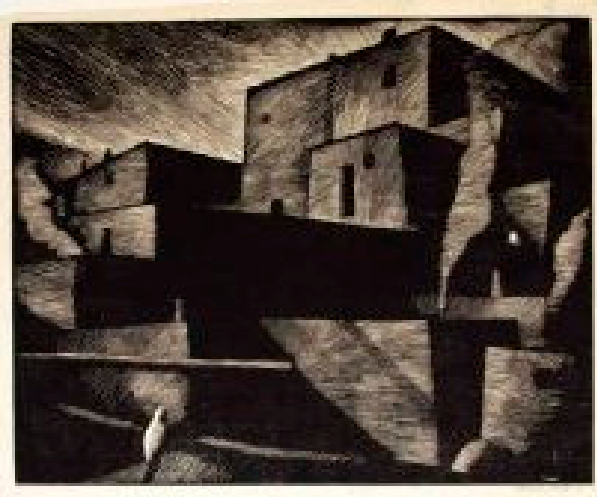

(a)

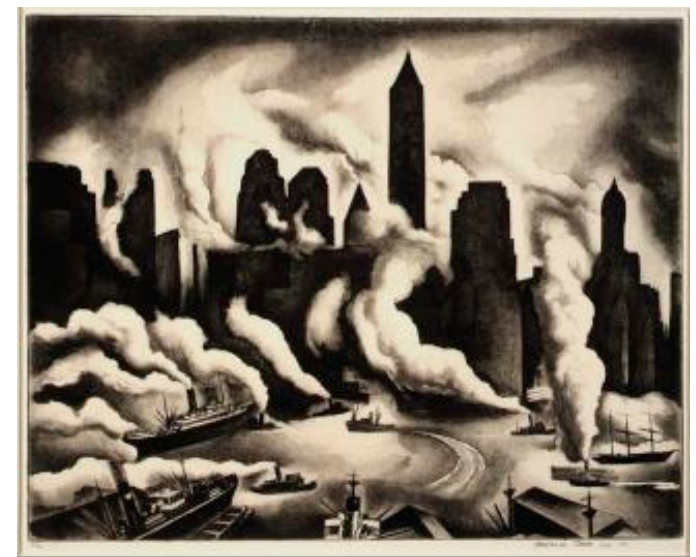

(b)

Figure 2. A widely traveled artist, Cook primarily divided his time between New Mexico and New York when he was not commuting for a specific assignment: (a) Howard Cook, Pueblo Moonlight (Taos Pueblo), 1927, woodcut on paper. Permanent Collection of the Roswell Museum and Art Center, Acquisitions Fund Purchase 1973.023.0001. Used with permission; (b) Howard Cook, Harbor Skyline, 1930, etching and aquatint on paper. Smithsonian American Art Museum, Museum Purchase, 1975.97.1. Used with permission.

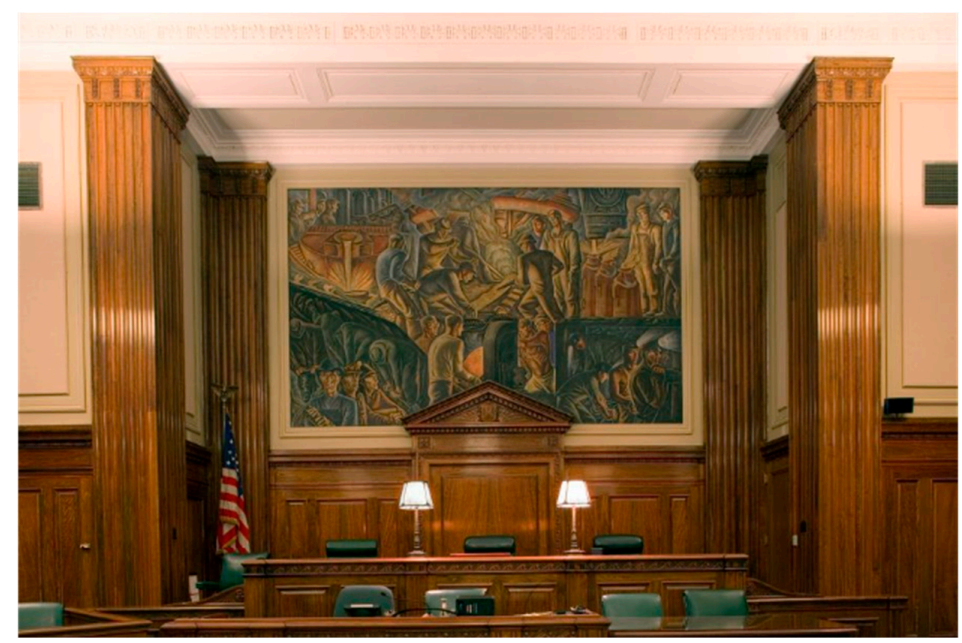

Figure 3. During the 1930s, Cook completed several frescoes through the U.S. Treasury Department, including this 1936 fresco depicting the steel industry in Pittsburgh, Pennsylvania. Highsmith, Carol M., photographer. Fresco "Steel Industry" at U.S. Courthouse and Post Office, Pittsburgh, Pennsylvania. Photograph. Retrieved from the Library of Congress, www.loc.gov/item/2011647744/. Public Domain.

While these projects enabled Cook to begin producing new work, his most significant wartime opportunity materialized in early 1943 when he received an invitation to join the War Art Unit. Initially envisioned as a commission restricted to military artists, the initiative's focus changed significantly when General Frederick Osborn appointed Federal Art Project muralist George Biddle (1885-1973) to assist in the endeavor (Harrington 2002, p. 5). Using his connections at the Associated American Artists in New York, the Metropolitan Museum of Art, and the National Gallery of Art, Biddle devised a new proposal that recruited civilians in addition to enlisted artists. He then drafted an invitation list of 32 individuals with 13 alternates, many of whom had participated in the Federal Art Project and related programs. Officially in operation by February 1943, the War Art Unit assigned participants to different geographic regions and provided art supplies. Civilians received an officer's title, while artists already serving in the military retained their assigned rank. Biddle hoped this revised program would produce American combat art that rivaled the pathos of Goya's Horrors of War and similar works 
(Bohm-Duchen 2013, pp. 92-93; Harrington 2002, pp. 7-10). As a seasoned federal artist, Cook recognized the new project as a chance to reinvigorate his career while contributing to the Allied effort.

Cook's assignment took him to the South Pacific, a critical region in the Pacific Theater and the public imagination. From August 1942 to February 1943, American and Japanese forces engaged in a grueling campaign over the island of Guadalcanal, the first major Allied offensive effort against the Japanese Empire (Adams 1994, p. 104; Bennett 2009, pp. 14-16; Frank 1992, pp. vii, 614; Stafford 1943). On the home front, civilians read eyewitness accounts about Guadalcanal, including Ira Wolfert's Battle for the Solomons and Richard Tregaskis's Guadalcanal Diary, both published in 1943. The film version of Guadalcanal Diary, released in November of that year, also emphasized the South Pacific's significance to domestic audiences (Basinger 2003, p. 65; Roeder 1993, p. 22). Cook arrived at New Caledonia's capital, Noumea, in late May, and he remained there until early August. Appointed to the rank of colonel, he supervised two other artists assigned to the same region, Aaron Bohrod (1907-1992) and Charles Shannon (1914-1996) (Cook 22 May 1943; Harrington 2002, pp. 10-12). ${ }^{6}$

As an art correspondent, Cook produced hundreds of drawings documenting the daily lives of soldiers. In keeping with his artistic practice, he worked from direct observation, although he did take photographs of vegetation for future reference (Cook 1945). ${ }^{7}$ Most of these sketches focus on the mundane aspects of camp life rather than battle conditions, showing recreational activities, training exercises, or tent furnishings (Figure 4). While Cook spent most of his tenure in the South Pacific as a civilian officer with the freedom to travel and sketch as needed (Cook 22 May 1943), in late June and early July, he experienced combat conditions by participating in the Invasion of Rendova, when American troops seized the critical Munda airfield base on New Georgia Island (Rickard 2013). During the expedition, he also visited Guadalcanal, encountering trenches containing human remains and other vestiges of the historic campaign that had concluded only a few months earlier (Cook 4 July 1943). After returning to New Caledonia, he had no desire to repeat the experience, writing to Latham that, "As far as combat business goes, I've got my bellyful of that-two big sketchbooks full" (Cook 30 July 1943). ${ }^{8}$ Despite his ambivalence, or perhaps because of it, he drew himself into the war's picture.

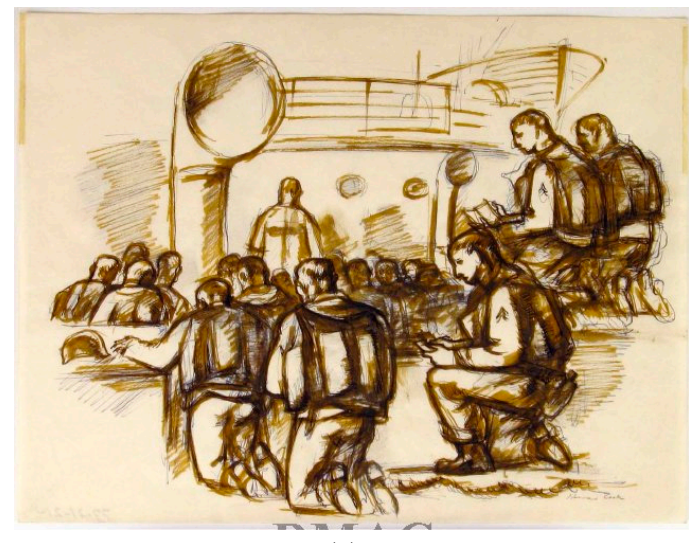

(a)

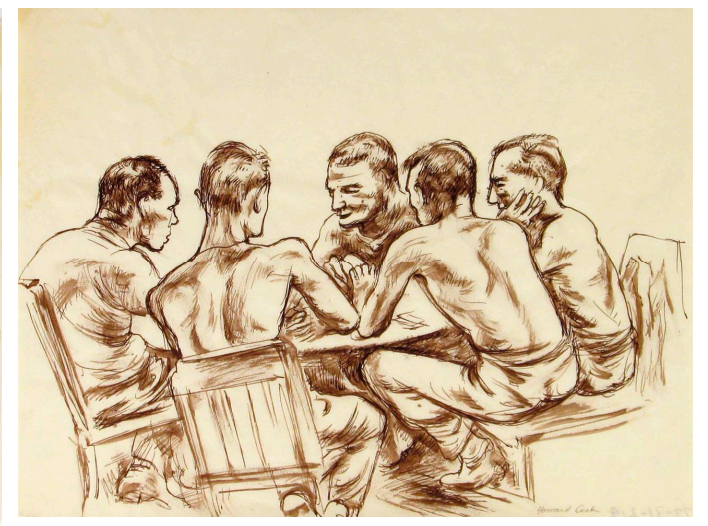

(b)

Figure 4. Most of Cook's drawings focus on noncombat activities: (a) Howard Cook, Easter Service (WWII), 1943, ink on paper. Permanent Collection of the Roswell Museum and Art Center, Gift of the Artist, 1973.031.0214. Used with permission. (b) Howard Cook, Card Game, 1943, ink on paper. Permanent Collection of the Roswell Museum and Art Center, Gift of the Artist, 1973.031.0219. Used with permission.

6 Howard Cook to Barbara Latham, 22 May 1943, shelf 9, box 12, folder 6, Howard Cook Papers, Roswell Museum and Art Center Library and Archives, Roswell, NM.

7 Howard Cook, "Invasion and Landing in North Solomon Islands," 1945, hand-written lecture, shelf 9, box 12, folder 6 Howard Cook Papers, Roswell Museum and Art Center Library and Archives, Roswell, NM.

8 Howard Cook to Barbara Latham, 30 July 1943, shelf 9, box 12, folder 6, Howard Cook Papers, Roswell Museum and Art Center Library and Archives, Roswell, NM. 


\subsection{The Self-Portrait Group}

All three iterations of Self-Portrait in a Foxhole depict Cook taking cover in a trench during an air raid on Rendova. As Cook's first serious encounter with combat conditions, the attack left a vivid impression and became one of his most well-documented experiences with the War Art Unit. Immediately after the raid, Cook completed two small drawings while still in his trench, adding detailed inscriptions to emphasize their significance (Figure 5). He also wrote a detailed sensorial description of the incident in a letter to Latham, where he recounted the damp texture of the soil, the piercing sounds of airplane gunfire, and his inability to see what was happening around him (Cook 4 July 1943):

At about this time someone down the line shouted "air raid!" and the cry was taken all the way up the line. All work stopped, now promptly got into their sticky holes and out of sight, a colonel whom I had seen watching sitting in his car comfortably while his aide sweated out a shelter jumped down and hid himself. I wasted no time in stretching out the length of my trench getting my head and helmet down as much as possible and not realizing until afterward [when] I saw the footprints that my feet stuck up exposed all the time. I was just able to wedge into the brown goo and didn't worry at all about rubbing the clay into my clothes and shoes. I could hear planes circling around apparently over the shipping in the bay. Could hear the short rat-tats of machine-gunning and soon the roar of bombers came down over and lay their eggs in our midst. I don't remember being particularly scared, had been too busy to work up a scare and was concerned mostly with protecting myself. I condensed myself so intensely in my hole that I did not realize the show was over until I saw a jeep drive up and almost come in on top of me. Felt rather funny walking up out of such a cramped position into broad daylight.

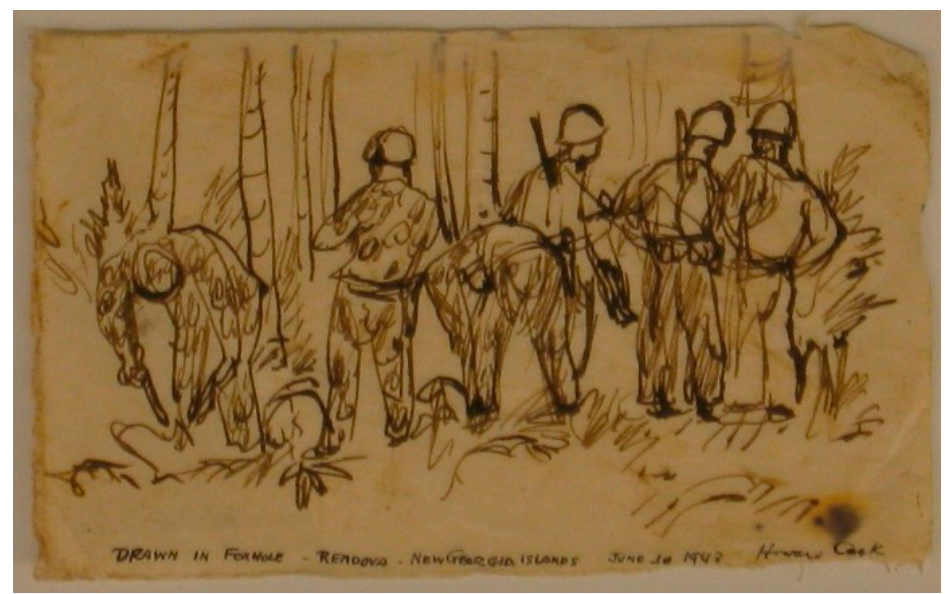

(a)

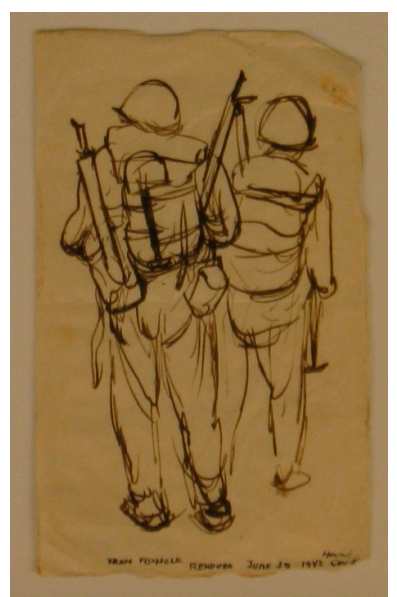

(b)

Figure 5. The two drawings Cook completed in the foxhole: (a) Howard Cook, Drawn in a Foxhole, Rendova New Georgia, 1943, ink on paper. Permanent Collection of the Roswell Museum and Art Center, Gift of the Howard Cook Estate, 1981.018.0391. Used with permission. (b) Howard Cook, From Foxhole, Rendova, 1943, ink on paper. Permanent Collection of the Roswell Museum and Art Center, Gift of the Howard Cook Estate, 1981.018.0392. Used with permission.

Most significantly, Cook completed three different versions of Self-Portrait in a Foxhole, including a mixed media drawing, an etching with aquatint, and an oil painting. Whereas Cook's other wartime drawings consistently focus on scenes he had witnessed, these works present an out-of-body experience, with the artist imagining how he might have appeared during the attack (Bohm-Duchen 2013, p. 96; 
Cook 1945; Henkes 2001, p. 12; Renn 2015, pp. 261-62). ${ }^{9}$ As a composition, Self-Portrait in a Foxhole reflects Cook's emphasis on clarity, with the artist using contrasting values and readily visible contours to distinguish himself from the surrounding foxhole. Yet, Cook's prominence within the scene also underscores its cramped, claustrophobic quality. The viewer looks down at Cook, as though assuming the perspective of one of the attacking planes or even the jeep that nearly drove over him afterward (Weems 2017, p. 88). Whereas many of Cook's other war sketches show downturned heads or averted eyes, giving his subjects a degree of anonymity, he looks out, establishing a connection between himself and the viewer. A pickaxe and shovel lie out of reach by his side, rendering him incapable of digging away from the viewer's gaze. Donning a helmet and heavy pack, Cook resembles a turtle peeking out from its shell, an animal hiding in a burrow, or more ominously, a torpedo being dropped. The foxhole itself appears equally ambivalent, suggesting either a protective shelter or an unfilled grave. The vegetation surrounding the trench seems to encroach on him as leaves and roots envelop him in a cocoon of damp soil and vegetal growth. In the painted version, in particular, the surrounding soil has a reddish color reminiscent of dried blood, accentuating the trench's wound-like quality. With its focus on a single, staring soldier, the Self-Portrait group shares affinities with Tom Lea's The 1000-Yard Stare, but whereas Lea's soldier stands out in the open and appears unresponsive to his surroundings, Cook's active, searching gaze remains confined to the vicinity of his trench. No matter how he successfully he manages to conceal himself, Cook's inability to fully perceive his surroundings beyond his trench renders him exposed and potentially visible to the enemy.

Cook's multiple iterations of the air raid suggest a commemorative quality not unlike the widespread habit of wartime souvenir collecting (Cook 25 June 1943) ${ }^{10}$ Throughout the war, both Allied and Axis troops acquired shell casings, weapons, and other material artifacts from the places where they served, objects that provided a sense of ownership over their wartime experiences while also anticipating a return to domestic life (Bennett 2009, pp. 243, 266). Cook's recollections of the air raid as articulated in his letters, drawings, and postwar lectures underscore a desire to commemorate the event, with each work memorializing different facets of the experience. If the sketches Cook completed in the trench document the place itself, for instance, Self-Portrait in a Foxhole emphasizes the emotional experience of the air raid (Cook 1945). By literally putting himself in the picture, Cook retroactively processes and reconciles the fear he likely suppressed during the initial attack.

Yet, unlike the informal intimacy of the trench sketches or his letters to Latham, Cook seems to have regarded the Self-Portrait group as more than private souvenirs. While the initial mixed media sketch may have been drawn for personal purposes, the creation of an intaglio print edition suggests the intent to circulate it widely within an art-buying public. The finished painting also implies a public audience, given Cook's exhibition history. He committed to the War Art Unit anticipating that his finished work would be exhibited or published, though he did not initially know in what form (Cook 22 May 1943; Cook 9 June 1943). ${ }^{11}$ While still on New Caledonia, he showed his paintings in an impromptu group exhibition, and after his return to the United States, several of his painted works toured publicly with the Army Art Program in 1944 (Cook 14 June 1943; War Finance Division 1943,

9 Although Cook based his work on direct observation, wartime conditions often prevented him from drawing what he saw in full detail in the immediate moment. Consequently, he often recreated scenes using soldiers as models and took photographs of vegetation and other details for future reference. Recreating an important war scene after the fact was not unusual, not only for safety reasons, but also because of the greater aesthetic freedom in terms of compositional arrangement. As Melissa Renn points out, one of the most iconic images associated with World War II, the flag-raising at Iwo Jima, was taken after the island had been secured, when Rosenthal had the leisure to rearrange his soldiers into a pyramidal formation reminiscent of Emanuel Leutze's Washington Crossing the Delaware.

10 Howard Cook to Barbara Latham, 25 June 1943, shelf 9, box 11, binder 1, Howard Cook Papers, Roswell Museum and Art Center Library and Archives, Roswell, NM. Cook also collected his own souvenirs, sending shells and bullet casings to Latham as materials for making jewelry.

11 Howard Cook to Barbara Latham, 9 June 1943, shelf 9, box 12, folder 6, Howard Cook Papers, Roswell Museum and Art Center Library and Archives, Roswell, NM. 
p. 11). ${ }^{12}$ While Self-Portrait in a Foxhole is not explicitly named in the exhibition's published checklist, the existence of both a printed and painted version suggests that he at least intended it for public view. ${ }^{13}$ Cook's time in the foxhole may have been deeply personal, but his decision to create multiple iterations in different media suggests that he wanted to share it. Moreover, given his assignment to document the overall Allied effort, it seems likely that Cook intended Self-Portrait in a Foxhole to reflect on general wartime conditions even as it highlighted the specificity of his experience. Whether intended for personal use or public exhibition, however, all three versions of Self-Portrait in a Foxhole highlight vulnerability, a quality that Cook explores through both his rendering of the surrounding landscape and his own passivity as a figure. This sense of vulnerability, as will be demonstrated later in this essay, recurs throughout his war drawings, suggesting his ongoing interest in it as a physical and emotional state.

\subsection{Active Ecology, Passivity, and Wartime Vulnerability}

One feature of the Self-Portrait group that highlights Cook's sense of exposure is its depiction of the jungle as an active presence, a feature that resonates with recent environmental history. As Simo Laakkonen and other environmental historians studying World War II have demonstrated, the local environment is no passive backdrop for human combat. Whether through fluctuating climate conditions, the presence of mosquitoes and other disease-carrying insects, or challenging terrain, the environment played a critical role in a battle's outcome (Laakkonen 2017, pp. 18-21). With the South Pacific, guerilla tactics became a key feature of battle due to the region's complex ecology. As Keio Tamura observes in his article on the documentary films of Damien Parer, the dense vegetation of the jungle could easily conceal soldiers, erasing the conventional battlefront and consequently transforming nearly every facet of the seen and unseen landscape into a potential battlefield (Tamura 2010, p. 118). Cook himself observed the lack of a clear battlefront during his experiences on Rendova and Guadalcanal, writing to Latham that "[i]t is so very difficult for us to actually get a look at this Pacific War as there is no "front" in the usual sense of the word, the front is all over the place and is always hidden" (Cook 13 July 1943). Cook's comment recalls similar observations of trench warfare during World War I, with combat zones becoming increasingly hidden the further one moved into the battlefield (Lubin 2017, p. 36).

Beyond concealing potential enemies, the ecology itself could prove dangerous, with soldiers more likely to contract insect-borne diseases such as malaria and dengue fever than battle wounds (Jarvis 2004, p. 92; Laurent 2017, pp. 168-69). As Judith Bennett has demonstrated in her scholarship on the South Pacific during World War II, simply contributing to the war effort could increase the seeming hostility of the environment, with the clearing of trees for campsite construction producing stagnant pools of water that encouraged mosquito breeding (Bennett 2009, p. 49). The jungle's resilience further underscored the vigor of its vegetation. Adapted to resist cyclones and other extreme natural disasters, South Pacific jungles can recover from damage with unsettling rapidity, underscoring its vitality (Bennett 2000, p. 17).

Cook explores the complexity of the jungle by portraying himself as an isolated figure in an unfamiliar environment. While his letters explicitly state that he concealed himself from airplanes, no enemy soldiers or equipment appear in the Self-Portrait works. Instead, he shows himself on the lookout for a seemingly invisible enemy, an experience that must have been jarring to an artist like Cook. Based in Taos at least part-time since 1926, Cook often worked in high desert environments with low humidity, conditions that enable viewers to see for extensive distances with almost uncanny clarity.

12 Howard Cook to Barbara Latham, 14 June 1943, shelf 9, box 12, folder 6, Howard Cook Papers, Roswell Museum and Art Center Library and Archives, Roswell, NM. Cook writes that "We had our gala opening yesterday, Sunday afternoon June 13, from 14.00 to 17.00 Army time. We spent all the morning putting the things up and then cleaning up the room... It was not exactly a professional gallery job as these New Zealand "huts" are on the rough side, for such a job anyway. However the interior had been newly painted white and we cleared back a lot of engineers equipment so nobody would break any bones."

13 The catalogue for this specific exhibition, The Army at War, by American Artists, only includes the names of paintings. While the exhibition included drawings, specific titles are not listed. 
Shortly after his arrival in the South Pacific, Cook familiarized his new surroundings by describing them as an eerily similar yet hyper-saturated version of the American Southwest, writing to Latham that "[i]t reminds me in many ways of a strangely weird New Mexico landscape with the colors, purple, burnt sienna, golden ochre and all earth reds up to scarlet gashing through brilliant grassy green forested hillsides" (Cook 29 May 1943). ${ }^{14}$ During his time on Rendova, however, his descriptions of the environment changed. No longer able to identify parallels with New Mexico, however tenuous, he instead commented on the vegetation's overwhelming density, writing that "generally the jungle ceiling is solid overhead, very damp and clammy underneath and just a tangle of vine and stuff making a solid green mess" (Cook 4 July 1943). In contrast to the sparse flora of the high desert, the abundant vegetation of the South Pacific jungles must have appeared overwhelming in its excess, while its ability to conceal both enemy and Allied soldiers underscored its potentially dangerous quality. The jungle rendered every facet of its ecology a potential shelter as well as a trap, blurring the battlefront into an all-consuming, immersive experience.

In Self-Portrait in a Foxhole, Cook highlights the jungle's ambivalent role as both protector and aggressor by emphasizing its dynamic qualities. For the initial mixed media sketch, Cook designates himself from the trench by painting the soil white, encompassing his body with a halo that diffuses out into the leafy vegetation surrounding the trench. Even as Cook distinguishes himself from the earth, however, a branching root reaches over his shoulder, as though attempting to grab him. The vegetation's grasping becomes even more apparent in the other two works. In the intaglio print, the cluster of roots over his shoulders appears larger than in the initial drawing, now almost touching his helmet, while the leafy fronds reaching toward his leg have also become more pronounced. In the painted version, the roots and vegetation almost entirely cover the left side of Cook's body, his right leg now barely visible through the leaves. The contrast in values between his body and the trench has also become less distinguished, while strokes of muddy red soil now appear on his uniform, blurring the distinction between himself and the ground. In each iteration, Cook seems to increasingly meld with the landscape even as he demarcates himself from it through contrasts in values and clearly defined outlines. The trench may provide some semblance of protection from the air raid, but its vegetation also appears to be on the verge of swallowing him. Whether the jungle is a protective shelter, a source of danger, or both, Cook portrays it as an active presence in contrast to his more passive, prone body.

Cook's seeming passivity is striking when compared to other sketches he completed during the Rendova campaign, as well as his overall oeuvre. In many of Cook's war drawings, soldiers actively move supplies, dig trenches, and otherwise appear at work (Figure 6). A similar emphasis on the labor of male bodies also appears in Cook's Steel Industry and other New Deal-era frescoes, which highlight the work of capable, industrial men. Nor was Cook unique in highlighting the active male body. As Erika Doss argues, muscular, idealized males became especially popular subjects for public art during the Great Depression in response to a crisis of masculinity, as high unemployment challenged the status of men as breadwinners (Doss 1997, pp. 53-55). By showing empowered men actively shaping the environment around them, Cook's New Deal-era imagery not only proffered a more optimistic future to viewers, but also suggested the healing capabilities of male work. Despite the prominence of working women during the Great Depression, a significant amount of New Deal art shows men, specifically white men, ushering in a brighter future (Doss 1997, pp. 58-59). As the United States entered World War II, these heroic male bodies followed suit by appearing on posters and other propaganda, their confident masculinity assuring victory (Jarvis 2004, pp. 10-11). While Cook's war art did not serve propagandistic functions, he still intended to show his work publicly through exhibitions and publications. Not surprisingly, then, his studies continue many of the conventions of his New Deal frescoes concerning the capable male body.

14 Howard Cook to Barbara Latham, 29 May 1943, shelf 9, box 12, folder 6, Howard Cook Papers, Roswell Museum and Art Center Library and Archives, Roswell, NM. 
In comparison to the male figures in his other work, Cook portrays himself more modestly, reflecting its more personal nature as a self-portrait. Already in his forties by the time he joined the War Art Unit, Cook noted the age difference between himself and the soldiers stationed on New Caledonia, as when he writes to Latham that "they are a right lot, very young, fresh and intelligent, like the youngsters I was teaching only recently" (Cook 16 June 1943). Recalling his own experiences on Rendova, he credited his ability to complete the operation to experience rather than a youthful physique, noting how his previous work as a quartermaster in the 1920s seemingly developed a muscle memory that enabled him to participate in the landing without falling behind (Cook 4 July 1943). Yet, it is not Cook's age that the Self-Portrait group highlights, but his passivity in combat conditions. Cook does not attack but instead hides on his stomach, a position that contrasts with his other war art. His soldiers may appear weary or beleaguered at times, but whether they dig trenches, carry equipment, or march, they actively shape their circumstances through their work (Figure 7). Self-Portrait in a Foxhole, by contrast, does not offer a conventionally heroic image. Cook does not stand upright to face potential gunfire, but instead lies down in an act of self-preservation. Instead of holding his pickaxe and shovel, Cook has drawn his tools out of reach, further underscoring his inability to actively change his present circumstances. Taking cover from the artillery of an unseen plane, Cook is not engaging the enemy, but protecting himself.

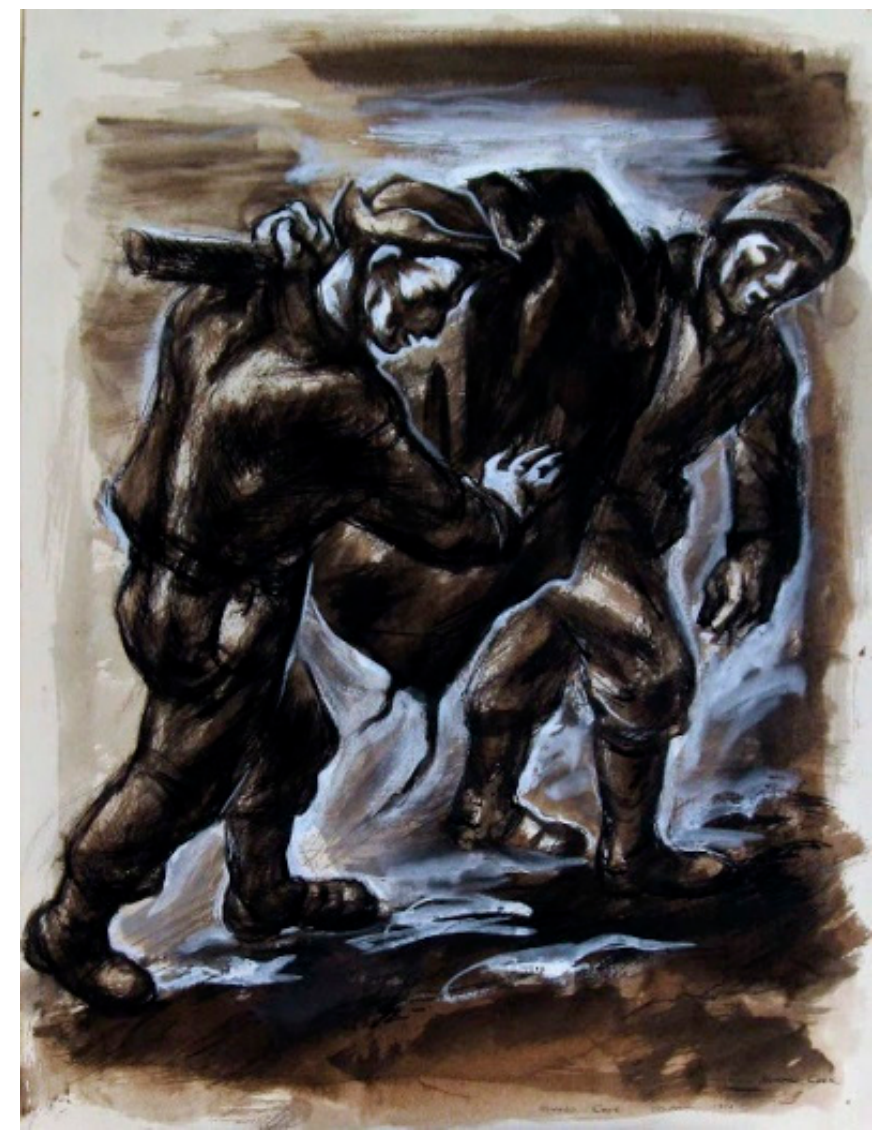

Figure 6. Howard Cook, Carrying Equipment, Guadalcanal, 1943, mixed media on paper. Permanent Collection of the Roswell Museum and Art Center, Gift of the Artist, 1973.031.0228. Used with permission. 


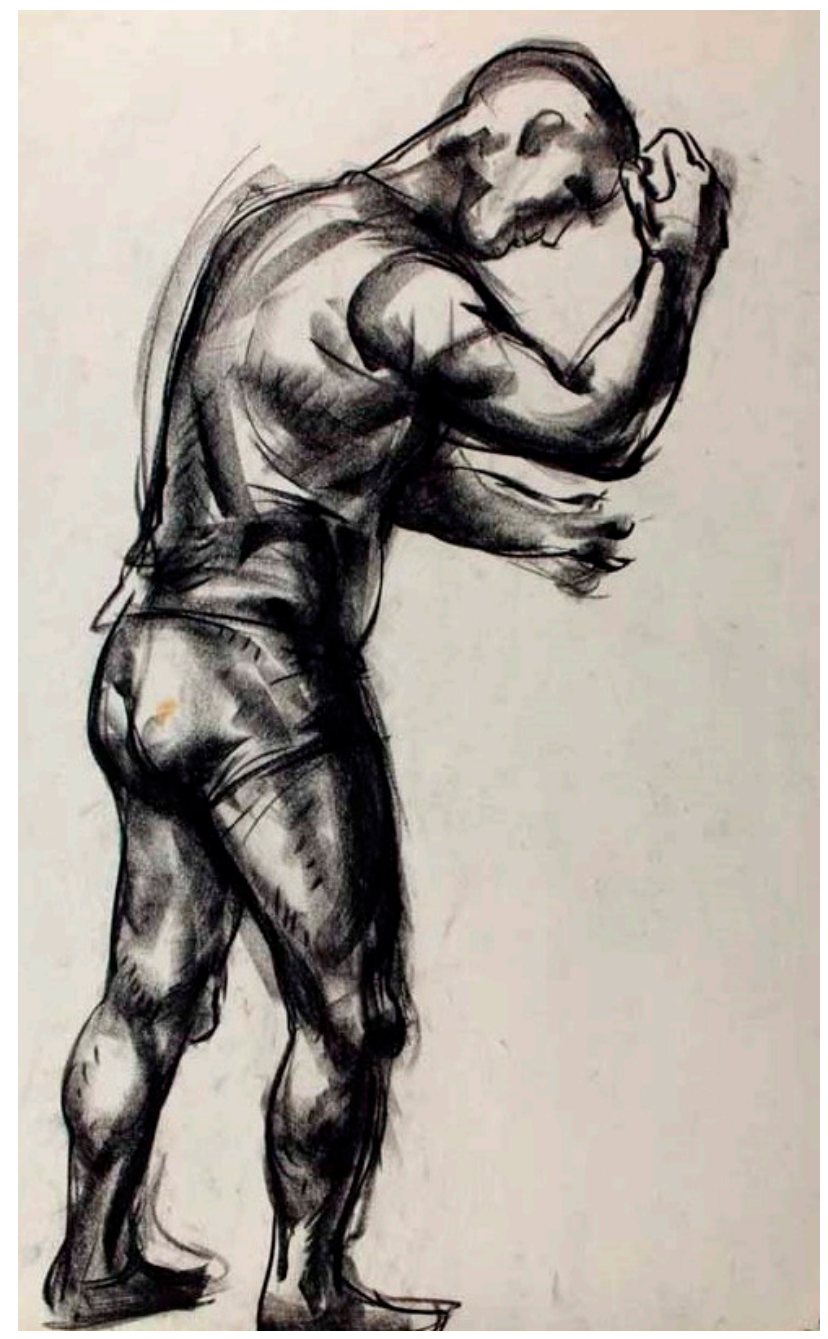

Figure 7. Howard Cook, Figure Study for War Painting, ca. 1943-1945, charcoal on paper. Permanent Collection of the Roswell Museum and Art Center, Gift of the Artist, 1973.025.0076. Used with permission.

By highlighting a moment of passivity during combat conditions, Cook's Self-Portrait suggests the realities of modern warfare and its effects on fighting. As Christina Jarvis argues in The Male Body at War, the long-distance capabilities of artillery nullified hand-to-hand combat and other traditional opportunities for demonstrating masculine prowess, writing that "a destructive technology that could atomize bodies from a great distance, shelling threatened both the wholeness of the body and the masculinity of men who could not directly confront this enemy fire" (Jarvis 2004, p. 93). While movies and recruitment posters continued to depict hand-to-hand combat and other conventional battle techniques, in actuality, soldiers were more likely to die from long-distance artillery, their bodies often dismembered (Jarvis 2004, p. 93). Cook himself recognized the seemingly random nature of combat conditions, writing to Latham that "I had been told there are two kinds of bullets or bombs or whatever comes after you, one is labeled with your name and the fatalists say you can't avoid it but the really serious one is labeled 'to whom it may concern,' and that's the one to watch out for" (Cook 4 July 1943). If Cook's New Deal frescoes, such as Steel Industry, showcase working men in control of their surroundings, the Self-Portrait group shows Cook at its mercy. In the disorienting landscape of the Rendova jungle, Cook's potential attacker is as likely to manifest as an airplane as it is a soldier hiding in the surrounding vegetation. Focusing on vulnerability rather than the violence associated with long-distance artillery also likely enabled Cook to appease censorship policies. In both his letters and sketches, Cook endeavored to provide timely material while withholding critical information about recent battles or maneuvers. After being reprimanded for communicating too much detail about 
the Rendova invasion, in particular, he actively shared his sketches with censors to ensure that they contained no relevant information (Cook 30 July 1943). ${ }^{15}$

Yet, why would Cook choose to center this vulnerability on himself? After all, many of his other Rendova sketches focused on anonymous soldiers, so why did he opt for specificity in the Self-Portrait group? While part of Cook's decision to name himself as the subject may reflect a desire to document his unique experience, rendering the foxhole scene explicitly as a self-portrait also enables him to comment on war without denigrating the reputations of the soldiers with whom he served. Throughout his letters, Cook expresses his admiration for the soldiers, as when he writes to Latham that "... the guys who are going through it and carrying out their terrible jobs are made of wonderful stuff. They are all American and there's not an ounce of soft stuff in them" (Cook 13 July 1943). Regardless of how he felt about the war, Cook respected the soldiers who served in the South Pacific, but showing one of these recruits hiding in a foxhole might have sent the wrong impression to viewers. By making the work explicitly about himself, Cook highlights the trauma of warfare without questioning the heroism of Allied soldiers. Air raids may have been a regular occurrence in World War II battlefields, but the experience Cook depicts is explicitly his own.

At the same time, however, Cook's focus on vulnerability is not limited to the Self-Portrait group. While these three works might be the most explicit renderings of exposure within his wartime oeuvre, his other works also explore the idea of vulnerability through their renderings of unfamiliar jungle environs and the physical and emotional difficulty of war work. Beyond its shared content, Cook's war oeuvre also documents his ongoing stylistic experimentation; as he explored, he sought increasingly expressionistic means to convey his observations.

\subsection{The Self-Portrait Group and Cook's Wartime Oeuvre}

The Self-Portrait group remains unusual in Cook's wartime oeuvre because it represents the only known instance of the artist depicting himself in wartime conditions. Yet, examining his war art as a whole through the lens of Self-Portrait in a Foxhole demonstrates recurring themes in both subject matter and style. Visually, Self-Portrait reflects stylistic changes that occurred in Cook's work during his time on Rendova. For his drawings executed before the campaign, Cook used graphite, ballpoint pen, or pen and ink to produce crisp, legible sketches, rarely using more than one medium for each work. Many of these studies feature soldiers isolated against white backgrounds, and when he does include finished settings, he delineates the foreground figures by rendering the background in lighter tones. As drawings, they reflect the stylistic tendencies of his earlier work (Figure 8), with clearly defined forms, reflected light, and tightly controlled ink washes giving his work a clear, almost luminous quality.

During the Invasion of Rendova, however, Cook shifted his focus, with his sketches becoming increasingly somber in both subject and style. Instead of band practices or letter reading, he began depicting more overtly combat-related activities such as trench digging, the transport of wounded soldiers, and burials (Figure 9). He also experimented with his style by combining media and incorporating new materials such as white paint into his work, creating painterly, grisaille sketches that suggest the textures of muddy soil and dense vegetation. His expressive use of painterly materials, particularly the juxtaposition of white paint and black ink, gives many of these pieces a chiaroscuro effect that underscores the drama and solemnity surrounding the soldiers' work. While many of

15 Howard Cook to Barbara Latham, 30 July 1943, shelf 9, box 12, folder 6, Howard Cook Papers, Roswell Museum and Art Center Library and Archives, Roswell, NM. Cook's approach might have changed had he stayed longer. During the first year of the war, when the outcome of Allied efforts remained largely undetermined, censors made sure that war media for home front audiences was highly sanitized. By mid-1943, when Allied victory seemed more certain, censors became concerned about disinterest in the war effort and began allowing the publication of more graphic images to encourage the continued purchasing of war bonds. Had Cook remained in the South Pacific for a longer period, his work may have also manifested a more overtly violent character. Given his unwillingness to endure military action a second time, however, it is equally likely that he would have continued working in a more understated direction. 
these newer works still use contrasting values to demarcate soldiers from their surroundings, some drawings such as Jungle Camouflage begin blurring the distinctions between figure and landscape, with similar tonal values merging the soldiers' bodies with the vegetation. Compared to the clean linearity of his earlier prints and drawings, the Rendova sketches exude a messy, gestural quality, with Cook employing wet, loaded brushstrokes, dripping pigment trails, and other kinds of painterly mark-making to evoke his dense jungle environs. As a body of works, the Self-Portrait group exudes qualities associated with both Cook's older style and his more recent, gestural studies. With its thicker brushstrokes and energetic line work, Self-Portrait in a Foxhole is in keeping with Cook's other expressionistic works from the Rendova campaign, while its overall compositional clarity and use of legible contours reflect the style of his earlier work.

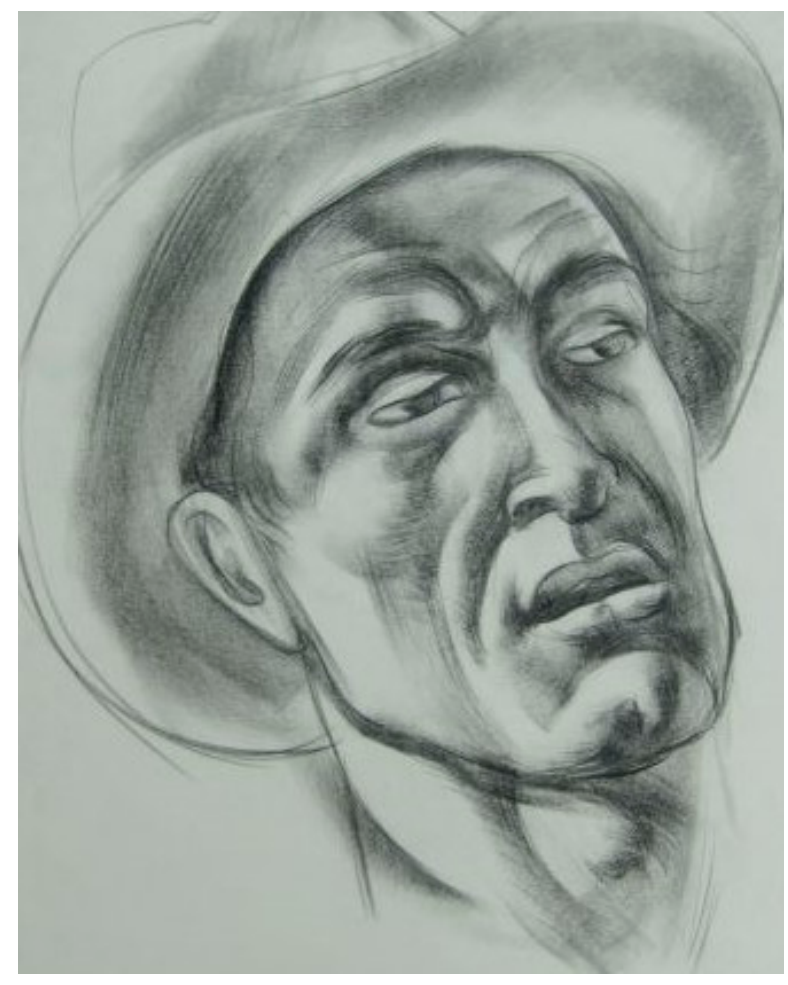

Figure 8. This study for the San Antonio frescoes exemplifies several hallmarks of Cook's drawing style during the 1930s and early 1940s, including clearly defined forms, substantial modeling to suggest three-dimensionality, and ample reflected light. Howard Cook, Study for San Antonio Mural, ca. 1935-1938, charcoal on paper. Permanent Collection of the Roswell Museum and Art Center, Gift of the Artist, 1973.025.0017. Used with permission.

The Self-Portrait group shares more than stylistic affinities with Cook's other works, however. In terms of subject matter, the vulnerability that underpins Self-Portrait in a Foxhole also recurs in his other drawings, including many of the Rendova sketches. In works like Two Men in a Foxhole, Cook uses strong contrasts between light and shadow to emphasize the nakedness of the two soldiers working, their upper bodies rendered in bold strokes of white paint. Stripped to their underwear, the two men pause from their digging and look up, their bodies standing out against the darkness of the trench around them. Cook emphasizes both their musculature and their vulnerability to bodily attack, recalling Renaissance-era depictions of Saint Sebastian and other martyrs. In other Rendova works, Cook also features soldiers at rest during marches and other exercises, emphasizing the ongoing physical toll of combat conditions. 


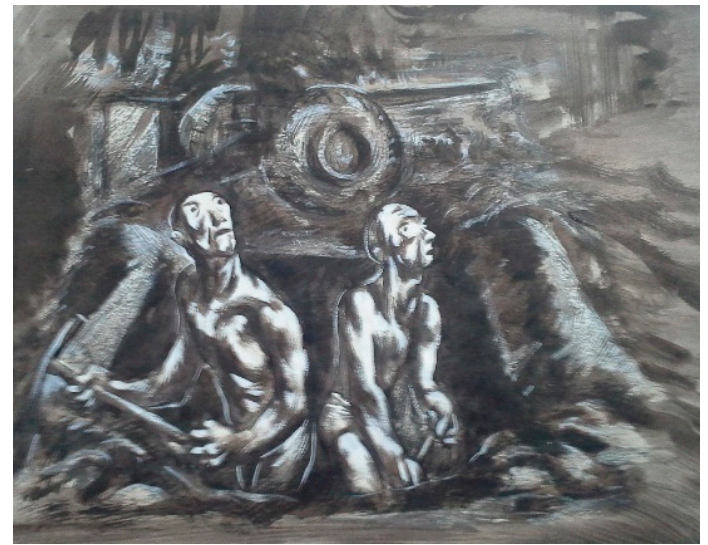

(a)

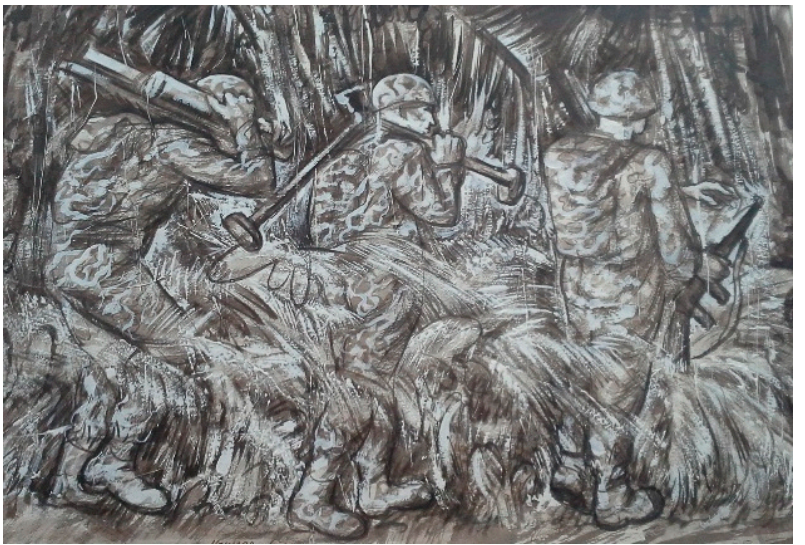

(b)

Figure 9. The Rendova sketches reflect stylistic experimentation, as Cook attempted a more expressionistic approach: (a) Howard Cook, Two Men in a Foxhole, 1943, mixed media on paper. Permanent Collection of the Roswell Museum and Art Center, Gift of the Artist, 1973.031.0223. Used with permission. (b) Howard Cook, Jungle Camouflage, 1943, mixed media on paper. Permanent Collection of the Roswell Museum and Art Center, Gift of the Artist, 1973.031.0229. Used with permission.

Cook's interest in vulnerability as rendered in Self-Portrait in a Foxhole also appears in works less focused on combat. While he did complete finished paintings showing the landing at Rendova, for instance, other compositions such as The Ship-Bombers' Homecoming show officers resting during a plane ride, with one soldier asleep under a blanket (Figure 10). Similar to his earlier frescoes, this painting relies heavily on reflected light and strong contrasts between light and shadow to give the composition clarity, but whereas earlier works such as Steel Industry highlight active male labor, this work shows soldiers at rest, their bodies huddled together in response to the cold environment of the airplane cabin (Cook 4 July 1943). While the scale of the figures in relation to the cabin provides the work with a sense of monumentality, the varied expressions on the soldiers' faces, with some looking animated while others appear weary, provide a sense of intimacy to the scene. The soldiers here are not in immediate mortal danger as Cook appears in his self-portrait, but through his depictions of rest, he nonetheless suggests their vulnerability.

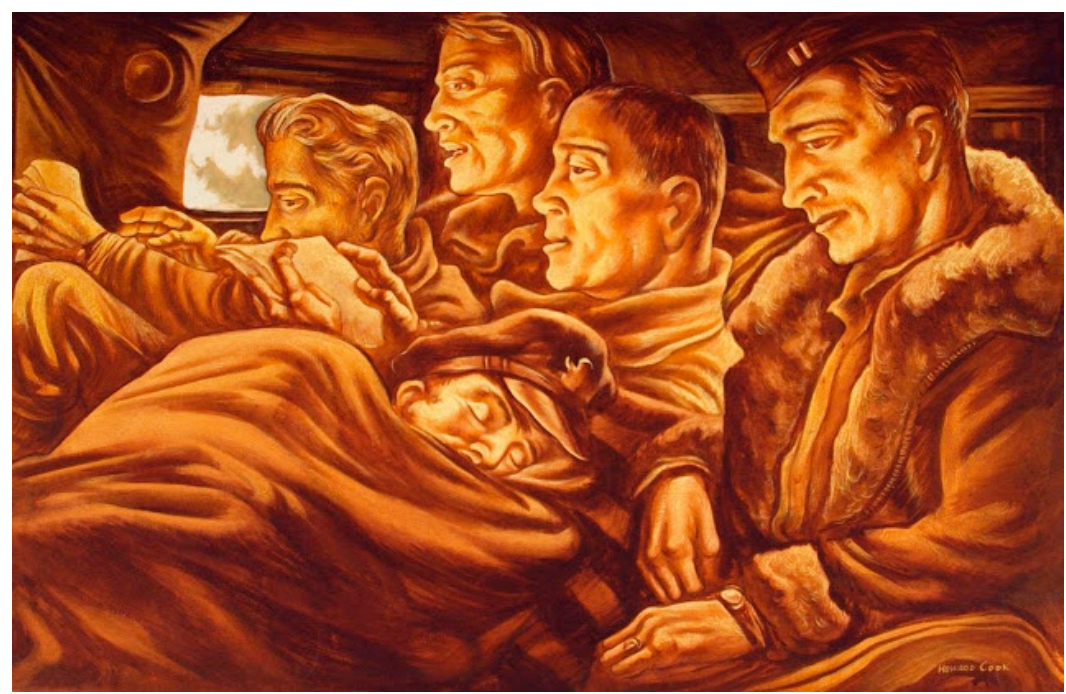

Figure 10. Howard Cook, The Ship Bombers' Homecoming, 1943-1944, tempera, ink on illustration board. Permanent Collection of the Roswell Museum and Art Center, Gift of the Artist, 1973.031.0242. Used with permission. 
Such an emphasis on both the more mundane facets of war and vulnerability as an experience reflects Cook's motives as an artist. Although he did paint scenes of action that emphasized strong, capable troops, throughout his time in the South Pacific, Cook preferred highlighting quieter moments over overt combat. He justified his preference for more subdued topics by citing the instructions from the War Art Unit itself, writing to Latham that "we get bored as hell at times here-in fact one of our directives from Biddle telling us of subject matter to paint is 'the boredom of war."' (Adams 1994, p. 70; Cook 13 July 1943; Harrington 2002, p. 4). ${ }^{16}$ In a later letter, Cook describes the importance of depicting homesickness, writing to Latham that "there is a lot of bravado that the coup muster to show that they are real fighting men but many times their sadness and helplessness over here is apparent" (Cook 2 August 1943). In showing scenes of respite, boredom, or longing, Cook explores war's effects on soldiers beyond the immediate traumas of combat. By recording his own experience, Self-Portrait in a Foxhole encapsulates what he endeavored to do throughout his tenure with the War Art Unit: to provide a nuanced impression of the conflict. In keeping with his letters to Latham, Cook explored the boredom, vulnerability, and action underpinning the Allied effort. Whether he is showing soldiers at work or rest, he focuses on their humanity. Like his own depiction in Self-Portrait in a Foxhole, Cook's war drawings argue that these soldiers are ordinary people experiencing extraordinary circumstances. For all its focus on vulnerability, however, Self-Portrait in a Foxhole does suggest a subtle triumphal undertone. Cook's work may highlight his potential exposure to attack and relative inability to actively combat it, but the fact that he sketched it at all informs the viewer that he survived the raid. As with souvenir collecting, Cook takes ownership of the air raid experience. Self-Portrait in a Foxhole may highlight his exposure, but it nonetheless depicts a survivor.

\section{Discussion: Cook's War Art in Context}

As a body of work, Cook's South Pacific drawings belong to a tradition of war art and literature that openly interrogates the consequences of combat for the troops who participate in it. From the caustic poetry of Wilfred Owen to the expressionist compositions of Otto Dix, artists and writers throughout the twentieth century have articulated war's emotional and physical toll through creative means, whether describing corrosive gas attacks or painting the effects of amputation and other war injuries on the body. While there is an especially strong tradition of soldiers and veterans articulating their own experiences through visual and literary means, civilians such as Howard Cook have also commented on war through their work. As David Lubin argues, even John Singer Sargent, an artist better remembered for his aristocratic portraits rather than his protestations of war, painted a striking rendition of soldiers affected by mustard gas in his 1919 painting Gassed (Lubin 2017, pp. 35-37). While World War I inspired an extensive and volatile creative response, artists and writers also explored World War II's deleterious effects on soldiers. The paintings of Tom Lea are among the most striking examples of wartime art to emerge from the period, with compositions such as The Price and The 1000 Yard Stare confronting both the physical and emotional violence of warfare on soldiers. Other artists such as Ogden Minton Pleissner or Peter Hurd explored the destruction of bombing and other long-distance attacks through watercolor studies of destroyed buildings and other modern ruins (Bohm-Duchen 2013, pp. 95-96).

Within this larger tradition of war art, Cook's paintings reflect an ongoing engagement with the repercussions of warfare on the soldiers who participated in it, but what he adds is both the variety of subjects he addresses within that broader theme and his sense of place. By living among the soldiers and recording his impressions of their work, Cook produced a body of sketches and drawings that offer a fairly comprehensive interpretation of the South Pacific experience for American soldiers. While the Rendova sketches focus on combat-related activities, other studies highlight how soldiers

16 Howard Cook to Barbara Latham, 13 July 1943, shelf 9, box 12, folder 6, Howard Cook Papers, Roswell Museum and Art Center Library and Archives, Roswell, NM. 
used recreation to provide release from their surroundings, whether through watching movies or staging variety shows. In addition to the expressionistic Rendova sketches, Cook's studies of trees, seascapes, and other natural elements also underscore the significance of place itself to the wartime experience, whether it occurs in the jungle or the desert. Cook's observations of war's effects on soldiers and the way they responded to those conditions may follow an established tradition, but the quantity and variety of works he produced during his tenure in the War Art Unit offer an exceptionally replete record of his impressions. Given his unwillingness to engage in combat conditions a second time, his broader focus on recreational activities offers a particularly fruitful area for future work, with an emphasis on how soldiers used letter writing, media consumption in the form of films, and performance to reassert a sense of autonomy in response to the vulnerability wartime conditions created.

Cook's omissions are also as significant as his inclusions. More specifically, his studies depict white soldiers almost exclusively, despite the decided involvement of indigenous peoples in the war effort (Bennett 2000, p. 127). Cook expressed interest in drawing indigenous populations in the South Pacific and even completed a few preliminary sketches, but he ultimately decided to focus on white American soldiers. Cook justified his omission by citing the mandates of his assignment, explaining to Latham that "[a]s far as the natives go ... I know their jungle life is worth a lot but this whole expedition of ours here is so definitely concentrated on the war angle and the white man's place in it that all my thinking goes into that one big direction"(Cook 5 July 1943). ${ }^{17}$ While the whiteness of Cook's war drawings and the erasure of indigenous populations from Allied efforts in the Pacific Theater demand further consideration, investigating these subjects fully is a separate project from the present essay.

Beyond Cook's career, the War Art Unit itself merits further research. Unlike the Federal Art Project and other initiatives affiliated with the New Deal era, the War Art Unit remains little studied as a federal art initiative. While scholars such as Melissa Renn have explored commercial enterprises such as Life magazine and its role in the production of World War II images, the War Art Unit itself and the work its participants produced have received comparatively little attention, though efforts have been made to address this program. Keith Harrington and Monica Bohm-Duchen have both written about the War Art Unit, though their research focuses primarily on narrating its chronology. In 2000, PBS aired the documentary They Drew Fire, which focuses on the War Art Unit and included an accompanying website. Most significantly, the Army Art Collection, which houses most of this material, plans to open a museum in June 2020, which should render this work more visible to scholars and general visitors alike (The National Museum of the United States Army 2019). ${ }^{18}$

As for Cook's career, his tenure with the War Art Unit yielded mixed results. Cook originally intended to stay in the South Pacific for six months, but Congress abruptly shortened his assignment when it voted to terminate the War Art Unit on 1 July 1943, effective in September (Cook 25 July 1943). ${ }^{19}$ The initiative's sudden conclusion shocked participating artists and incensed the art world. While federal representatives cited the program's expenses as the primary reason for its premature conclusion, the liberal politics of its artists, at least one of whom maintained Communist sympathies, likely influenced the decision. After Congress announced the vote, Life magazine offered to hire on all civilian artists enrolled in the program. Of those nineteen War Art Unit participants, only two declined the proposal (Harrington 2002, pp. 14-15, 17).

One of those artists was Cook himself. Wary of the impending influx of artists at Life and the competition for publication space, he accepted a personal invitation to become an art correspondent at

17 Howard Cook to Barbara Latham, 5 July 1943, shelf 9, box 12, folder 6, Howard Cook Papers, Roswell Museum and Art Center Library and Archives, Roswell, NM.

18 The website for the National Museum of the United States Army lists a June 2020 opening date. Dedicated more broadly to the history of the U.S. Army, the exhibition spaces will include artwork from its collection.

19 Howard Cook to Barbara Latham, 25 July 1943, shelf 9, box 12, folder 6, Howard Cook Papers, Roswell Museum and Art Center Library and Archives, Roswell, NM. 
Collier's magazine and remained in the South Pacific until the end of August to gather more sketching material (Cook 30 July 1943). Although his new patrons requested that he concentrate more exclusively on scenes of action, Cook continued to focus on the war's more mundane aspects, writing to Latham that "[i]n spite of my sponsor's wishes to have some blazingly dramatic pictures of conflict I am happy to have not seen so much of that, feeling that so many of the little human happenings of men along the way have meant even so much more importance." ${ }^{20}$ A few months later, a selection of his finished paintings appeared in the 13 November 1943 issue of Collier's, accompanying an article by journalist Ira Wolfert discussing the psychological dimensions of jungle warfare (Wolfert 1943, pp. 18-19, 66). While these first paintings showed combat on the ground, Cook planned to dedicate future works to aviation, a subject that interested him after experiencing several flights in and around the South Pacific (Cook 31 July 1943). ${ }^{21}$

Despite this promising beginning, Cook's affiliation with Collier's ultimately yielded limited results. Although he did complete several paintings based on his original sketches (Figure 11), they did not appear in subsequent issues, likely the result of insufficient funding (Ebie 2015). ${ }^{22}$ Although Cook probably did not paint Self-Portrait in a Foxhole in response to his frustrated war art career, given the politics behind the project's cancellation and his brief tenure at Collier's, his work retroactively gains new poignancy. Grounded in his trench, he watches for unseen planes, a subject he wanted to paint but would never get to do on the scale he intended.

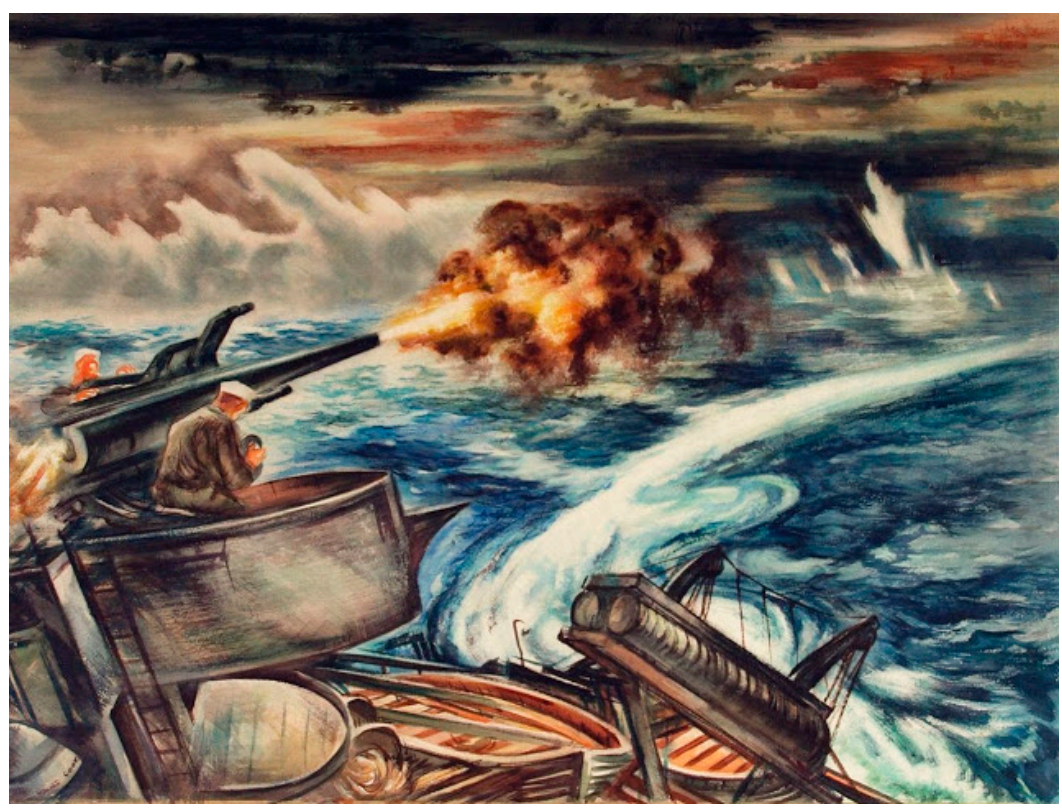

Figure 11. The back of this watercolor features a stamp from Collier's magazine, suggesting that it was intended for publication but did not appear in subsequent issues. Howard Cook, Firing from the After-Gun Turret, 1943, watercolor on paper. Permanent Collection of the Roswell Museum and Art Center, Gift of the Artist, 1973.031.0042. Used with permission.

While the War Art Unit initially yielded limited results for Cook, it exerted a lasting influence on his subsequent career. Cook may not have been able to publish as extensively in Collier's as he

20 Howard Cook to Barbara Latham, 25 July 1943, shelf 9, box 12, folder 6, Howard Cook Papers, Roswell Museum and Art Center Library and Archives, Roswell, NM.

21 Howard Cook to Barbara Latham, v-mail, 31 July 1943, shelf 9, box 12, folder 6, Howard Cook Papers, Roswell Museum and Art Center Library and Archives, Roswell, NM.

22 Cook's personal correspondence in the Roswell Museum's archives contains several caption-like descriptions that the artist had drafted for paintings, but these were never printed. 
had hoped, but he did complete several oil paintings and a handful of prints, some of which were exhibited publicly in shows such as The Army at War, on view at the National Gallery and other venues in 1944 (War Finance Division 1943, p. 11). The War Art Unit also influenced Cook's use of materials. Before the war, he rarely worked with oil paint, preferring watercolor, egg tempera, and other media that enabled him to showcase his Precisionist-infused aesthetic through meticulous cross-hatching and similar drawing techniques. As he developed his war sketches into finished compositions, however, Cook began experimenting with oils and continued using them for the rest of his career (Cook 10 July 1943; Ebie 2015). ${ }^{23}$ The gestural expressions he explored in his wartime sketches also became more prominent in his later work (Figure 12), with his overall style becoming increasingly abstract (Duffy and Duffy 1999, p. 20).

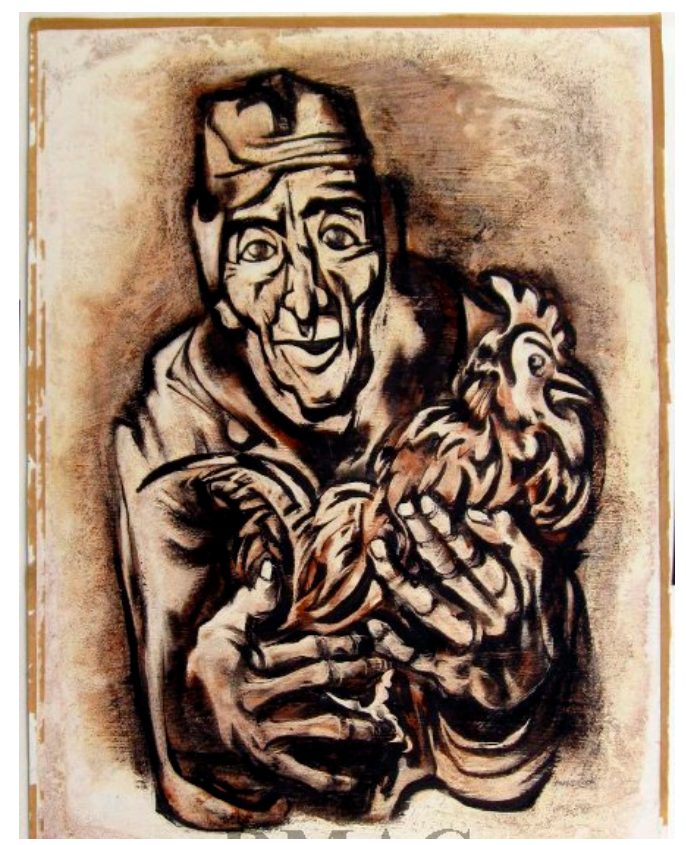

Figure 12. An example of Cook's later work. Howard Cook, Vicente with Fighting Cock, 1952, pastel and mixed media on paper. Permanent Collection of the Roswell Museum and Art Center, Gift of the Artist, 1973.031.0006. Used with permission.

Cook's war art also experienced a brief but compelling return to the public eye during the 1960s. While the Army Art Collection accessioned most of Cook's finished paintings, he retained sixteen canvases, including the painted version of Self-Portrait in a Foxhole, along with hundreds of drawings, watercolors, and sketches. ${ }^{24}$ In 1967, more than twenty years after their initial creation, Cook publicly exhibited these sixteen paintings in Lubbock, Texas, and Roswell, New Mexico (Lubbock Avalanche-Journal 1967). After the exhibition, Cook donated these paintings to the New Mexico Military Institute, while the Roswell Museum gradually acquired his drawing collection. ${ }^{25}$

The exhibitions' timing reflects a broader resurgence of interest in World War II that occurred during the 1960s. In 1962, the Guadalcanal Campaign resurfaced in the public imagination when author James Jones published his semi-autobiographical war novel, The Thin Red Line, which would

23 Howard Cook to Barbara Latham, 10 July 1943, shelf 9, box 12, folder 6, Howard Cook Papers, Roswell Museum and Art Center Library and Archives, Roswell, NM. Cook writes to Latham, "However I believe the sketches I am getting out here have got the sort of meat in them I want. Some will make good material to whip up large, and I am seriously considering sometime to break out in oil."

24 I do not know how he managed to do this.

25 The New Mexico Military Institute is also located in Roswell, a few blocks north of the Roswell Museum. It has a small art collection focused on the American military. 
be adapted to film in 1964. Movies such as Kelley's Heroes, Catch-22, and Tora! Tora! Tora! were also released in the late 1960s and early 1970s, further indicating the extent of renewed interest in World War II during this period (Allison 2018, p. 126). Yet, the resurgence of Cook's drawings, like many of these newer war films, suggested more than mere commemoration. For viewers in the 1960s, the jungle settings Cook had rendered through ink and paint likely evoked another, more immediate military conflict currently preoccupying the American public: Vietnam. Indeed, an article from the Lubbock Avalanche-Journal explicitly connected the paintings to the Vietnam War, stating that "the showing of these paintings is of special interest and historical significance because of our own forces being heavily involved in fighting for the freedom of Vietnam today (Lubbock Avalanche-Journal 1967). While Cook did not state explicitly his feelings toward the Vietnam conflict, his expressionistic renderings of jungle environments and wearied soldiers likely left an impression with viewers.

What Cook's decision to exhibit his war art does suggest, however, is that he believed his interpretation of war remained relevant. He may have only served as an art correspondent for a few months, yet the images he sketched remain striking testaments not only to the Allied campaign in the South Pacific, but also to the experience of war for the soldiers who endure it. Self-Portrait in a Foxhole and Cook's other wartime works both embody and transcend the Solomon Islands, encapsulating the boredom, fear, and exhaustion of warfare. Whether he is depicting the physically demanding work of digging through thick, damp soil to create a temporary shelter, the respite of consuming a ration, or the time-suspending tension of an air raid, Cook's wartime works capture the physical and emotional toll not only of combat, but also of war as an all-encompassing experience. Self-Portrait in a Foxhole may have featured Cook's experience specifically, but as a body of work, his drawings and paintings address the different ways that war can affect soldiers. War may be conceived, implemented, and often condemned as an abstraction, but Cook's drawings, like many great examples of war art, remind viewers that its participants are human.

\section{Materials and Methods}

This article relies on the Howard Cook Archive at the Roswell Museum and Art Center in Roswell, New Mexico. The war-related materials include Cook's letters and V-mails to Latham, occasional journal entries, a lecture Cook delivered in 1945, and captions for paintings intended for publication in Collier's. The Howard Cook archive, along with the rest of the materials available at the Roswell Museum and Art Center Library, is open to the public and available by appointment. The Roswell Museum art collection includes hundreds of Cook's wartime sketches, along with a few finished watercolor paintings. The New Mexico Military Institute in Roswell has sixteen oil paintings. Additional writings and artworks from Cook are housed at Syracuse University. Cook's war art is also part of the Army Art Collection in Washington, DC.

Funding: This research received no external funding.

Conflicts of Interest: The author declares no conflict of interest.

\section{References}

Adams, Clinton. 1983. American Lithographers, 1900-1960: The Artists and Their Printers. Albuquerque: University of New Mexico Press.

Adams, Michael C. C. 1994. The Best War Ever: America and World War II. Baltimore: The Johns Hopkins University Press. Allison, Tanine. 2018. Destructive Sublime: World War II in American Film and Media. New Brunswick: Rutgers University Press.

Basinger, Jeanine. 2003. The World War II Combat Film: Anatomy of a Genre. Middletown: Wesleyan University Press. Bennett, Judith. 2000. Pacific Forest: A History of Resource Control and Contest in the Solomon Islands, c. 1800-1997. Cambridge: White Horse Press.

Bennett, Judith. 2009. Natives and Exotics: World War II and Environment in the Southern Pacific. Honolulu: University of Hawaii Press. 
Bohm-Duchen, Monica. 2013. Art and the Second World War. Princeton: Princeton University Press.

Cook, Howard. 1943. Sammi's Army. New York: Doubleday Garden City.

Doss, Erika. 1997. Toward an Iconography of American Labor. Design Issues 13: 53-66. [CrossRef]

Duffy, Betty, and Douglas Duffy. 1999. The Graphic Work of Howard Cook. Gaithersburg: Signature Book Printing.

Ebie, Teresa. 2015. Interview by Sara Woodbury. Personal Interview. Taos, NM, USA: Mabel Dodge Luhan House, October 16.

Frank, Richard B. 1992. Guadalcanal: The Definitive Account of the Landmark Battle. New York: Penguin Books.

Harrington, Peter. 2002. The 1943 War Art Program. Army History: The Professional Bulletin of Army History 55: 4-19.

Henkes, Robert. 2001. World War II in American Art. Jefferson: McFarland \& Company.

Jarvis, Christina S. 2004. The Male Body at War: American Masculinity During World War II. DeKalb: Northern Illinois University Press.

Laakkonen, Simo. 2017. Polemosphere: The War, Society, and the Environment. In The Long Shadows: A Global Environmental History of the Second World War. Edited by Simo Laakkonen, Richard P. Tucker and Timo Olavi Vuorisalo. Corvallis: Oregon State University Press, pp. 15-36.

Laurent, Helene. 2017. The Great Louse War: Control of Typhus Fever. In The Long Shadows: A Global Environmental History of the Second World War. Edited by Simo Laakkonen, Richard P. Tucker and Timo Olavi Vuorisalo. Corvallis: Oregon State University Press, pp. 155-74.

Lubbock Avalanche-Journal. 1967. War Art Correspondent and Wife to Exhibit Here. Barbara Latham Papers, 1902-1972. Washington: Archives of American Art, p. 29.

Lubin, David. 2017. Lies that Tell the Truth: American Artists in the Crucible of War. In World War I and American Art. Edited by Robert Cozzolino, Anne Classen Knutson and David M. Lubin. Princeton and Oxford: Pennsylvania Academy of the Fine Arts in Association with Princeton University Press, pp. 31-44.

Renn, Melissa. 2015. The Infamous Iwo Jima Flag-Raising: Iwo Jima Revisited. History of Photography 39: $253-62$. [CrossRef]

Rickard, John. 2013. Invasion of Rendova Island, 30 June 1943. Available online: http://www.historyofwar.org/ articles/battles_rendova_island.htm (accessed on 7 December 2019).

Roeder, George H., Jr. 1993. The Censored War: American Visual Experience During World War II. New Haven: Yale University Press.

Stafford, Jane. 1943. Unique in Medical History: 'Guadalcanal Neurosis' Plagues Invalids Returning from Fighting in the South Pacific. Pittsburgh: The Pittsburgh Press, Available online: https://news.google.com/newspapers?nid= $1144 \&$ dat $=19430523 \& \mathrm{id}=$ OVkbAAAAIBAJ\&sjid=ikwEAAAAIBAJ\&pg=3832,4557910\&hl=en $($ accessed on 1 December 2015).

Tamura, Keio. 2010. Shooting and Unseen Enemy: Images of Japanese Soldiers in Damien Parer's New Guinea Newsreels. The Journal of Pacific History 45: 117-33. [CrossRef]

The National Museum of the United States Army. 2019. Available online: http://thenmusa.org/index.php (accessed on 3 December 2019).

War Finance Division. 1943. The Army at War, by American Artists. Washington: United States War Department. Weems, Jason. 2017. Battle Over Sight: The Aerial Photographer and the Camoufleur. In World War I and American Art. Edited by Robert Cozzolino, Anne Classen Knutson and David M. Lubin. Princeton and Oxford: Pennsylvania Academy of the Fine Arts in Association with Princeton University Press, pp. 87-99.

Wolfert, Ira. 1943. The Japs Tried to Drive Us Crazy. Collier's, November 14, 18-19, 66.

(C) 2020 by the author. Licensee MDPI, Basel, Switzerland. This article is an open access article distributed under the terms and conditions of the Creative Commons Attribution (CC BY) license (http://creativecommons.org/licenses/by/4.0/). 